Nowoczesne Systemy Zarządzania

Zeszyt 16 (2021), nr 2 (kwiecień-czerwiec)

ISSN 1896-9380, s. 13-22

DOI: $10.37055 /$ nsz/139358

Modern Management Systems

Volume 16 (2021), No. 2 (April-June)

ISSN 1896-9380, pp. 13-22

DOI: $10.37055 / \mathrm{nsz} / 139358$
Instytut Organizacji i Zarządzania Wydział Bezpieczeństwa, Logistyki i Zarządzania

Wojskowa Akademia Techniczna

w Warszawie

Institute of Organization and Management Faculty of Security, Logistics and Management Military University of Technology

in Warsaw

\title{
The issue of activation of cognitive activity of undergraduates
}

\author{
Kwestia aktywacji aktywności \\ poznawczej studentów
}

\author{
Yevhen Starokon \\ Korolov Zhytomyr Military Institute, Department of Social Sciences, Ukraine \\ ksn_zvir@ukr.net, ORCID: 0000-0001-8833-0351 \\ Roman Dziubchuk \\ Korolov Zhytomyr Military Institute, Training Division, Ukraine \\ rd_zt@ukr.net; ORCID: 0000-0001-6224-456X \\ Yurii Korniichuk \\ Korolov Zhytomyr Military Institute, Department of Social Sciences, Ukraine \\ korniy.yg@gmail.com; ORCID: 0000-0002-0699-3811
}

\begin{abstract}
The article analyzes the place and role of the teacher in activating the cognitive activity of higher education students. It is stated that the teacher is a key figure in activating the cognitive activity of higher education students. The emphasis of his work should shift not to the transfer of accumulated knowledge at the moment, but to the formation of learning motivation. The analysis shows that most researchers in their work focus on cognitive and didactic and methodological areas of activation of cognitive activity. Issues directly related to the transformation of cognitive needs of higher education students through the optimization of pedagogical interaction have been little studied. The authors consider the task of intensifying educational activities through the use in pedagogical communication of didactic and psychological patterns and principles of educational interaction. The emphasis in such subject-subject interaction should be on, in particular, the formation of a hierarchy of personal needs necessary for higher education students. The article presents in graphical form the structure of the need-motivational sphere of higher education seekers with different strengths of learning motivation. Only positive emotion can restructure the hierarchy of needs of a person with low learning motivation. This thesis is confirmed by the result of the study of the correlation between the average score of higher education students for 5 years and the
\end{abstract}


level of satisfaction of their basic needs (according to A. Maslow). It is proposed to use, first of all, the technology of creating a situation of success in learning, active teaching methods, in particular, the method of projects, for the formation of internal motives for learning. The basis of the process of activating the cognitive activity of higher education teachers is his communicative repertoire: a set of communicative techniques, methods and technologies that provide him with the opportunity to form cognitive needs. The article presents such communicative skills that provide an opportunity to intensify the educational activities of higher education students during classes. In general, the article reveals the technological and motivational levels of the teacher's teaching activity, taking into account which he can more effectively manage the cognitive activity of higher education students.

Keywords: cognitive activity, motivation, hierarchy of needs, communication, activation

\begin{abstract}
Abstrakt. W artykule przeanalizowano miejsce i rolę nauczyciela w aktywizacji aktywności poznawczej studentów. Stwierdzono, że nauczyciel jest kluczową postacią w aktywizacji aktywności poznawczej studentów szkół wyższych. Akcent w jego pracy powinien zostać przesunięty nie na transfer wiedzy zgromadzonej w danym momencie, lecz na kształtowanie motywacji do nauki. $Z$ analizy wynika, że większość badaczy w swojej pracy koncentruje się na poznawczych i dydaktyczno-metodologicznych obszarach aktywacji aktywności poznawczej. Zagadnienia bezpośrednio związane z przekształcaniem potrzeb poznawczych studentów poprzez optymalizację interakcji pedagogicznej zostały zbadane w niewielkim stopniu. Autorzy rozważają zadanie intensyfikacji działań edukacyjnych z wykorzystaniem w komunikacji pedagogicznej wzorców dydaktycznych i psychologicznych oraz zasad interakcji wychowawczej. W takiej interakcji przedmiot-przedmiot należy w szczególności położyć nacisk na ukształtowanie hierarchii potrzeb osobistych, niezbędnych dla studentów szkół wyższych. Publikacja przedstawia w formie graficznej strukturę sfery potrzebowo-motywacyjnej osób ubiegających się o wykształcenie wyższe o różnej sile motywacji do nauki. Tylko pozytywne emocje mogą zmienić hierarchię potrzeb osoby o niskiej motywacji do nauki. Tezę tę potwierdza wynik badania korelacji między średnim wynikiem studentów szkół wyższych za 5 lat a poziomem zaspokojenia ich podstawowych potrzeb (według A. Maslowa). Sugeruje się przede wszystkim wykorzystanie technologii tworzenia sytuacji sukcesu w nauce, aktywnych metod nauczania, w szczególności metody projektów, do kształtowania wewnętrznych motywów uczenia się. Podstawą procesu aktywizacji aktywności poznawczej nauczycieli szkół wyższych jest ich repertuar komunikacyjny: zbiór technik, metod i technologii komunikacyjnych, które dają możliwość kształtowania potrzeb poznawczych. W artykule przedstawiono takie umiejętności komunikacyjne, które umożliwiają zintensyfikowanie działań edukacyjnych studentów na zajęciach. Ogólnie artykuł ukazuje poziom technologiczny i motywacyjny działalności dydaktycznej nauczyciela. Bierze się pod uwagę to, że może on skuteczniej zarządzać aktywnością poznawczą studentów.
\end{abstract}

Słowa kluczowe: aktywność poznawcza, motywacja, hierarchia potrzeb, komunikacja, aktywizacja

\title{
Introduction
}

In recent decades, due to the rapid development of science and technology, including information technology, the system of knowledge generation and transfer has changed dramatically. Today it is impossible to prepare a person for a lifelong professional activity at once, even in 5 or 6 years. At present, about $5 \%$ of theoretical knowledge and $20 \%$ of professional knowledge is updated annually (Lifelong education, 2020).

The unit of measurement of specialist knowledge aging, adopted in the USA, is the period of "half-life" of competence, i.e. its reduction by $50 \%$ due to new information spread, which shows that in many professions this period occurs in less than 5 years, i.e. in relation to higher education system in Ukraine it often happens before the graduation. The solution is to make a transition to lifelong learning, where basic education should be periodically supplemented by additional educational 
programmes and be organized not as a final, completed stage, but only as a basis or a foundation that is complemented by other programmes (Lifelong education, 2020).

Certainly, the introduction of a training system throughout the whole period of military service is extremely important as new methods, forms and techniques of combat operations are being developed for the Armed Forces of Ukraine, where new samples of armament and military equipment are being introduced almost every day. On the other hand, the pedagogical proficiency of research and teaching staff should ensure the cognitive activity of higher education students in the classroom nowadays in order to make the process of teaching an officer throughout the service conscious, enjoyable and effective.

The purpose of the study is to explore some aspects of teachers' pedagogical proficiency in promoting the cognitive activity of undergraduates in the classroom based on the reference study of pedagogical literature and analysis of pedagogical experience. The used test methods were as follows: reference study, theoretical analysis, analogy, comparison, abstraction, generalization, specification, statistical methods of data processing.

\section{Results and Discussions}

One of the first to draw attention to the role of the teacher in promoting the cognitive activity of students was J.A. Comenius: "Who still pays attention to the fact that a teacher before beginning to educate the student would arouse interest in knowledge in the same way and by his instructions would make the student able to learn, would cause him a great willingness to obey his teacher in everything?" (Comenius, 1982, p. 309).

"If anyone has no desire to study, it is because he does not understand the benefits of learning... or he is afraid of difficulties. Therefore, make an effort for him to understand how important it would be for him to know this or that, and soon he will want to know it, because human thought is characterized by love for what is better" (Comenius, 1982, p. 536).

"Start teaching only when the student has sufficiently awakened a taste to learn" (Comenius, 1982, p. 536).

In his study "Great Didactics" J.A. Comenius gave a very interesting example of the teacher's work with Themistocles: "...the teacher told him: 'ou, child, will not be mediocre; you will bring to the state either great good or great evil'. When they were later surprised that his [Themistocle's] personality had changed, he used to say: incompetent young horses become beautiful if they are properly trained" (Comenius, 1982, p. 536).

This example is more related to education than to learning, but J.A. Comenius believed that they were inseparably linked and did not exist without each other. 
Johann Pestalozzi made a significant contribution to pedagogical science in understanding the role of a teacher in forming an active and conscious attitude to the teaching of those who are taught. The pivot of all his works is the idea that learning is designed to awaken the activity of students, stimulate the development of their talents and creative potential to form the necessary skills and inner need to acquire knowledge: “... any human learning is nothing but the art of promoting nature to its own development, and this art is largely based on the proportionality and harmony of impressions that must be perceived..." (Pestalozzi, 1981, p. 81).

"There is no doubt that human mind is unequally receptive to the different forms in which knowledge is given to it in relation to the impressions evoked by learning. The art of finding those forms that most arouse the receptivity of the mind is the mechanism of the method of teaching, which every teacher must find in nature and transmit it for the benefit of art [learning]" (Pestalozzi, 1981, p. 81).

Yu. K. Babansky thoroughly understood the significance of the teacher's role in accelerating the cognitive activity of students. He wrote: "The stimulating influences of the teacher are aimed at the development of internal motivation for learning... With such an approach, the formation of positive attitude to learning... acts as an integral component of the system of teaching methods" (Babansky, 1989, p. 42).

The group of methods of stimulating and motivating learning by Yu. K. Babansky (1989) comprised methods of formation (self-formation) of cognitive interests, methods of formation (self-formation) of duty and responsibility in learning.

K. D. Ushynsky (2015, pp. 248-249) pointed out the importance of the teacher's role in the promoting the cognitive activity: “...no mentor should forget that his main duty is to prepare students for mental work, and that this duty is more important than the transfer of the subject itself".

He realized that the teacher could not repeat the same educational material for the twentieth time with the same enthusiasm, so he indicated the need to use the methods to enhance the cognitive activity. There were offered a number of techniques and methods of such enhancement (Ushynsky, 2015). Nevertheless, they are not listed in this study as they relate to schooling and cannot be explicitly used in the course of undergraduates training in the military educational institutions.

The outstanding Ukrainian scientist H.H. Vashchenko paid special attention to the distinction between active and passive methods, which differ "first of all in variability of educational goals for them. Passive teaching methods are aimed at the students to be given the assembled knowledge, while the purpose of active ones is to bring up students' initiative and creativity. Therefore, the roles of a teacher and a student in active and passive teaching methods are different. In passive methods the student is only the object of pedagogical influence of the teacher, in active ones the student is also the subject of the pedagogical process, that is, besides perceiving what the teacher presents, the student organizes his work independently" (Vashchenko, 1997, pp. 187-188). 
O. Vasiuk and I. Orynenko note that the experience of pedagogical activity in higher educational institution allows us to conclude that the most popular methods of stimulating the cognitive activity of students are the method of projects, situational analysis, "brainstorming", and gaming (Babansky, 1989).

These methods do help to enhance cognitive activity, although they have limitations on their use for lectures and classes.

At the present stage of pedagogy development, the main functions of the teacher are didactic (yet not to transfer knowledge, but to teach how to acquire them), developmental (creating favorable conditions for the development of creative potential of the learner) and educational (encouraging the learner to manage his own development) (Ziaziun, 2008).

The performed analysis shows that most researchers in their studies focus on either cognitive or didactic and methodological aspects of promoting cognitive activity, whereas the issues related directly to the transformation of cognitive needs have been studied insufficiently.

Let us refer to the opinion of Yu.K. Babansky (1989) who wrote about “... stimulating influences of the teacher aimed at the development of learning motivation..." (p. 42).

We present the actual motivation of the undergraduate in such a scheme (see fig. 1). We found that intrinsic motivation of learning can significantly determine the acceptance or rejection of the teacher's actions and strengthen or compensate for the situational factors of learning motivation.

It is obviously so that like any other activity the learning process of the undergraduate is determined by specific (cognitive) needs that are the part of the general structure of needs (see fig. 2).

It is clear that the efforts of the teacher in the latter case should be aimed at restructuring and developing a new hierarchy of personal needs of the higher education undergraduate and, of course, the relevant internal learning motives. Let us mention them: own development in the process of learning, obtaining new information, learning about the previously unknown, intellectual self-affirmation, etc.

As a rule, in the variety of pedagogical methods of stimulation teachers use praise or condemnation, the inclusion of the learner in active learning procedures, which should also stimulate cognitive activity.

Practice shows that many teachers in their work, ignoring the psychological patterns of development of internal motivation, contribute to the regression of learning motivation of students by external motivating actions. Such actions of educators can be subjectivity of assessment (unjustified underestimation or overestimation of grades), contemptuous criticism and derogatory characterization, punishment, insincere praise, etc. Such influences determine the learner's aim to avoid trouble with teachers or peers, hence the purpose of learning, as the acquisition of knowledge, becomes secondary. 


\section{Learning motivation}

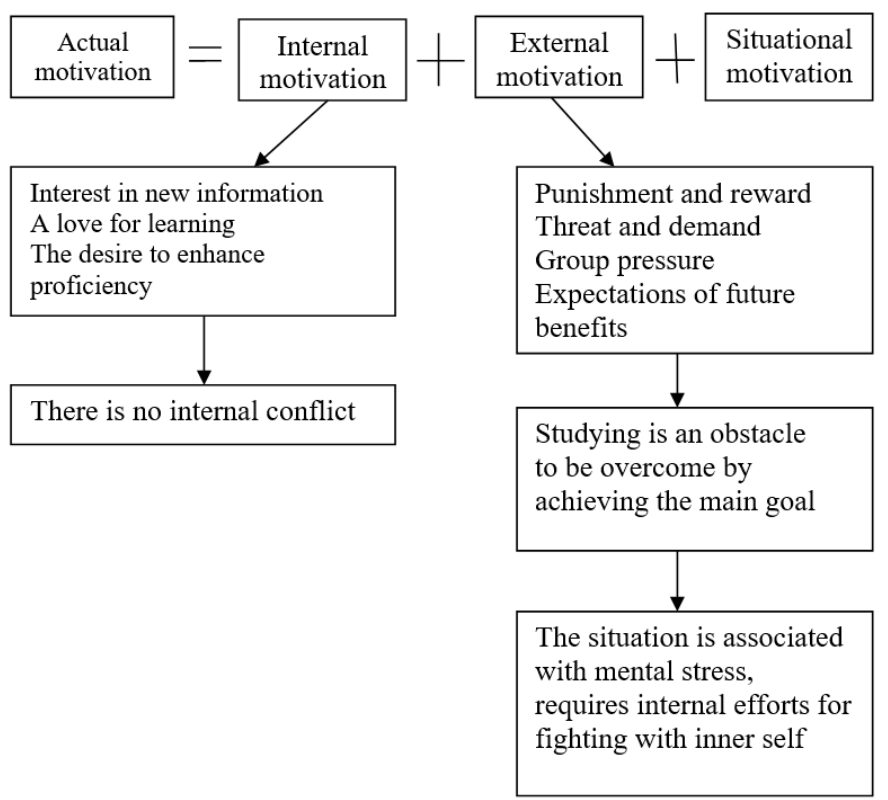

Fig. 1. Components of actual learning motivation of the student Source: Own elaboration

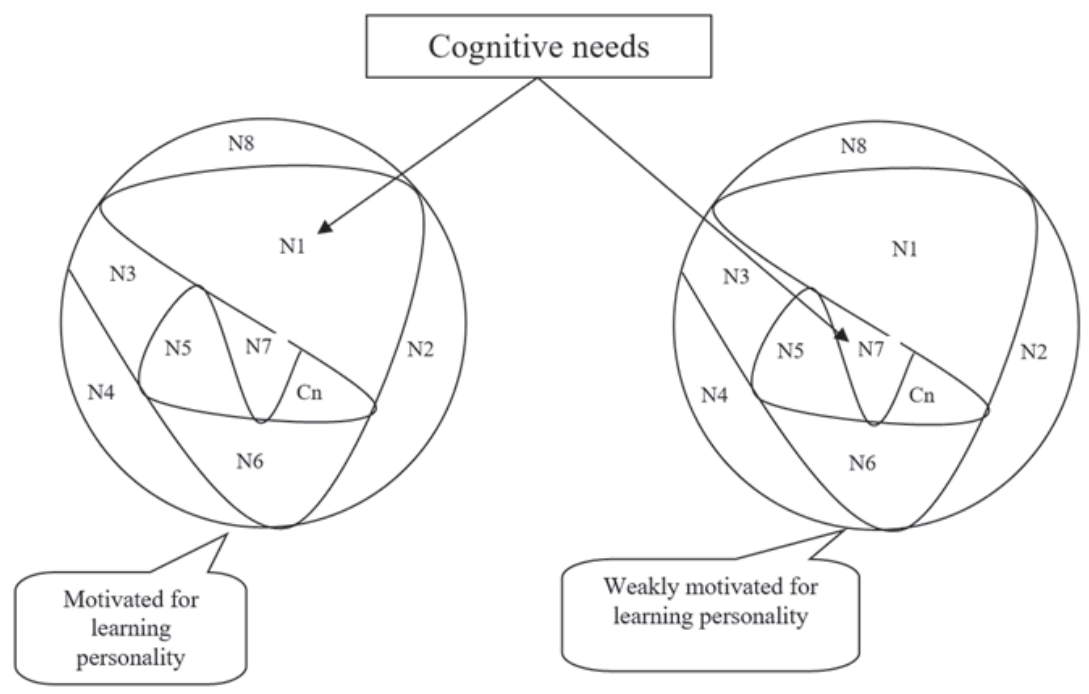

Fig. 2. Hypothetical structure of personality needs Source: Own elaboration 
Nothing but positive emotion can restructure the hierarchy of needs. This tenet is confirmed by the study of the correlation between the average cadet's grade for 5 years of study and the level of satisfaction of basic needs according to A. Maslow (see table 1), which was conducted by educators of the Department of Social Sciences of S.P. Korolov Zhytomyr Military Institute.

We see that for the development of internal cognitive motives of undergraduates the influence through fear (punishment, humiliation, condemnation, etc.) has the least prospects. In general, in the educational process, the use of such pedagogical methods has unpredictable consequences due to misunderstandings, insults and conflicts.

Table 1. Correlation between the average score and the satisfaction of basic needs of the individual

\begin{tabular}{|c|c|c|}
\hline $\begin{array}{c}\text { Psychological components } \\
\text { of the motivational realm }\end{array}$ & $\begin{array}{c}\text { Correlation } \\
\text { coefficient }\end{array}$ & Value \\
\hline Satisfaction with financial position & 0.45 & 0.1 \\
\hline Meeting the requirement for security & 0.25 & 0.5 \\
\hline Meeting the requirement for interpersonal relationships & 0.30 & 0.1 \\
\hline Meeting the requirement for respect & 0.42 & 0.1 \\
\hline Meeting the requirements for self-realization & 0.34 & 0.1 \\
\hline Level of subjective control & 0.56 & 0.1 \\
\hline
\end{tabular}

Source: Own elaboration

From our standpoint, an extremely effective method of forming internal learning motives is the pedagogical technology of creating a situation of success in learning (Krotiuk, Shchokina, Yandola, 2019). Its essence lies in such pedagogical actions of a teacher that provide psychological comfort and emotional satisfaction of the undergraduate for the results of his activities. It is necessary that all the tasks assigned to the student were taken from the area of the nearest development to be definitely achieved in the course of training.

As a positive reinforcement, it is advisable to use verbal assessment judgments, which include the teacher's recognition of the student's efforts. For example: "It's important for you because...", "I relied on you for a reason", "You especially succeeded in...", "I liked the way you...", etc.

A series of consistent learning tasks (even of low complexity), which culminate in success, strengthen cognitive needs and interests, make the learning process enjoyable and joyful. As a result, we have the psychological types of a winner and a leader motivated to achieve.

In another context, when a number of educational goals are not achieved by the learner, as well as educational tasks are not solved, one failure is followed by another, and as a result we have "educated helplessness", i.e. the individual motivated to avoid failure (Zaniuk, 2002). 
In general, the work of a teacher with the sphere of needs and motivation of the undergraduate is extremely difficult. In such a case one should be proficient not only in psychological field, but also be able to implement various educational technologies used for human sciences. Thus, in the modern world it is impossible to solve the problem to significantly increase the cognitive activity of students without such expertise and teacher educational competencies. We have already mentioned the features of verbal assessment of learning outcomes in creating a situation of success. However, assessment is the component of communication process, whether the communicative sphere of the teacher is much more meaningful and includes an extremely large number of communicative techniques, methods and approaches based on communicative skills and abilities. They are the basis of pedagogical competence. We have more than one evidence when a teacher with good theoretical background but with a deformed (undeveloped) sphere of pedagogical communication is unable to successfully carry out pedagogical activities.

In reference 10 the following communication skills are provided, which enable to intensify the educational activities of undergraduates during classes (Krasnytska, 2020):

- ability to overcome feelings of insecurity and anxiety during classes, to manage their psycho-emotional state during it;

- ability to establish contact with undergraduates and have influence on them;

- ability to arouse students' trust;

- ability to structure the speech, to pick up successfully relevant and interesting material, to write the convincing text for training session;

- ability to improvise during training session;

- ability to use verbal and nonverbal speech expediently;

- mastery of speech technique (breathing, voice, diction, orthoepy);

- ability to give reasons for one's opinion (persuade);

- ability to answer undergraduates' questions and lead a discussion or debate;

- ability to interest undergraduates, to manage their attention throughout the training session;

- ability to listen and hear;

- ability to carry out a full analysis and assessment of the lesson;

- self-presentation skills.

To apply such skills, it is very important to implement a subject-subject approach to learning in general and pedagogical communication in particular (Vitchenko, Ociodlo, 2017). An obstacle to its implementation is the need, the teacher's one as well, to demonstrate an authoritarian monologue to achieve the goal of military activity (engagement control and combat operations, command, etc.) in many official situations. At the same time, undergraduates must learn to exercise military 
authoritarian rule so as not to provoke such negative emotions of their subordinates as hostility, distrust, etc. Therefore, the variety of teacher's communicative repertoire (a set of methods and techniques of communication that he applies to enhance the cognitive activity of students during classes) comes to the fore within the pedagogical competence of a teacher. This communicative repertoire is concentrated in pedagogically effective styles of teacher's communication (democratic, dialogical, trusting), or in pedagogically ineffective ones (aloof-authoritarian, conflictual, passive-indifferent, manipulative).

\section{Conclusions and Findings}

1. Activation of cognitive activity of students should be based on the use of didactic and psychological patterns and learning principles. If we consider the process of interaction between a teacher and a listener during learning, the activation of cognitive activity of the listener is a catalyst for learning processes.

2. To motivate undergraduates for lifelong learning is an extremely difficult pedagogical task. It can be solved based on the pedagogical experience of previous generations adapting it to the modern challenges of the information age.

3. The teacher is the main character to enhance the cognitive activity of undergraduates. The emphasis of his work should be focused not on the transfer of currently accumulated knowledge, but to the formation of learning motivation.

4. The basis of the process of activating the cognitive activity of undergraduates by teachers is his communicative repertoire, i.e. a set of communicative techniques, methods and technologies that provide him with the opportunity to form cognitive needs.

The need to improve the pedagogical proficiency of research and teaching staff through the optimization of the process of pedagogical communication to form the cognitive needs of undergraduates is obvious. 


\section{REFERENCES}

[1] BaвANSKY, Yu.K., 1989. Izbrannyye pedagogicheskiye trudy [Selected pedagogical works], Moscow: Pedagogika [in Russian].

[2] Comenius, J.A., 1982. Izbrannyye pedagogicheskiye sochineniya [Selected pedagogical writings], Moscow: Pedagogika [in Russian].

[3] Krasnytska, O.V., 2020. Pedahohichna maysternist' vykladacha vyshchoyi viys'kovoyi shkoly [Pedagogical proficiency of a teacher of higher military school], Kyiv: Vydavnychyy dim «Kondor» [in Ukrainian].

[4] Квотіuк, V.A., Sнснокіna, N.V., Yandola, K.O., 2019. Pedahohichni tekhnolohiyi ta metody navchannya u skhemakh i tablytsyakh [Pedagogical technologies and teaching methods in diagrams and tables], Kharkiv: HNUPS [in Ukrainian].

[5] PestalozzI, J. (Ed.), 1981. Izbrannyye pedagogicheskiye sochineniya [Selected pedagogical writings], (Vol. 1-2), Moscow: Pedagogika [in Russian].

[6] SAit instytutu, http://old2.niss.gov.ua/contactus.html (15.02.2021).

[7] Ushynsky, K.D. (Ed.), 2015. Russkaya shkola [Russian school], Moscow: Institut Russkoy Tsivilizatsii [in Russian].

[8] VAshchenкo, H.H., 1997. Zahal'ni metody navchannya [Common teaching methods], Kyiv: Ukrayins'ka Vydavnycha Spilka [in Ukrainian].

[9] Vitchenko, A.O., Ociodlo, V.I., 2017. Pedahohika vyshchoyi viys'kovoyi shkoly [Pedagogy of higher military school], Kyiv: NUOU im. Ivana Chernyakhovs'koho [in Ukrainian].

[10] Zaniuk, S.S., 2002. Psykholohiya motyvatsiyi [Psychology of motivation], Kyiv: Lybid' [in Ukrainian].

[11] Ziaziun, I.A., 2008. Pedahohichna maysternist' [Pedagogical proficiency], Kyiv: SPD Bohdanova A.M. [in Ukrainian]. 